\title{
Environmental Communication Strategy of Langka Sekawan Community
}

\author{
$1^{\text {st* }}$ Didik Hariyanto \\ Communication Studies \\ Universitas Muhammadiyah Sidoarjo \\ Sidoarjo, Indonesia \\ didikhariyanto@umsida.ac.id
}

\author{
$2^{\text {nd }}$ Djarot Meidi Budi Utomo \\ Communication Studies \\ Universitas Muhammadiyah Sidoarjo \\ Sidoarjo, Indonesia \\ djarotmeidi@umsida.ac.id
}

\author{
$3^{\text {rd }}$ Ferry Adhi Dharma \\ Communication Studies \\ Universitas Muhammadiyah Sidoarjo \\ Sidoarjo, Indonesia \\ ferryadhidharma@umsida.ac.id
}

\begin{abstract}
This research aims to analyze the strengths, weaknesses, threats, and opportunities of the environmental communication strategy carried out by the Langka Sekawan community in supporting environmental sustainability. This type of research is qualitative with Strengths, Weakness, Opportunities, Threats (SWOT) analysis methods. The informants in this research were all members of the Langka Sekawan community and the society in the Baran, Winong Village, Pasuruan Regency. Data obtained from observations and interviews with informants then supported by research documentation data as a form of source and data triangulation. The results of the research stated that the communication strategy carried out by the Langka Sekawan community consisted of: (a) the problem assessment stage in the Baran, Winong Village, Pasuruan Regency (b) the planning stage by formulating work programs, determining segmentation and positioning, (c) designing message building to be conveyed, (d) the implementation phase of the work and evaluation program. The strength of the Langka Sekawan community's environmental communication strategy lies in creative and innovative Human Resources (HR) in compiling work programs and message designs, while the weakness lies in funding activities, because it still relies on the sale of hydroponics and handicraft sales. The opportunity owned by the Langka Sekawan community is the support of the surrounding community and academics, so that opportunities for funding assistance are wide open, while the most real threat comes from stakeholders and the internal community, namely the regeneration of members.
\end{abstract}

Keywords- Environmental Communication Strategy, Environmental Sustainability, Langka Sekawan Community

\section{INTRODUCTION}

The issue of environmental sustainability received a lot of attention from various parties, especially the government, academics, Non-Government Organizations (NGOs), and the industrial world. Indonesia is the second largest country in the world in terms of plastic waste contributor, which is 3,21 million of metric tons per year, after China which contributes 8,81 million of metric tons per year. In a research conducted by, [1], [2], [3] it was mentioned that there needs to be synergy between the government, academics, NGOs and industry in building public awareness of the impact of environmental damage caused by the main waste, especially plastic waste.

Synergy between institutions, especially industry involvement is clearly needed. The interaction between humans and the environment is a critical social science study that is totally different from the study of science, especially biology. This study involves analyzing the material exchange between people and their environment, as material production and reproduction that forms the foundation of all societies [4].

Clark \& Foster [5] continued Florence Kelley's idea that environmental degradation stems from social relations and the operation of industrial capitalism. The importance of Kelley's ecological thinking is rooted in the analysis of industrial production in creating an unhealthy environment where people spend the most productive hours in the public domain, its part in adding pollution to the surrounding environment and its role in producing degradation of life.

From the explanation above, this research has taken a different focus, which is aimed in analyzing the active role of community groups that are independently involved in preserving the environment. What is meant independently is the absence of relations with the government and the private sector or industry. Langka Sekawan Community, lived in the Baran, Winong Village, Gempol District, Pasuruan Regency, East Java. Langka Sekawan Community was established on October 23, 2016 by all 11 members with a background of workers and students. Despite not having organizational legality, the Langka Sekawan Community plays an active role in spreading environmentally conscious messages, both verbally, visually and audio-visual.

The targets of environmental communication Langka Sekawan Community are not only the surrounding community, but on a national scale. The environmental preservation activities carried out by Langka Sekawan as a social activity have been independently funded by community members by selling crops, local specialty cake, producing and marketing community merchandise, such as clothes, hats and eco-friendly drinking places. National-scale activities such as the "Caring for Green Space" program are carried out on mountain slopes with the aim of reforestation. The majority of Caring for Green Space participants were obtained through the Instagram social media network @Langkasekawan.

The formulation of the problem presented is how the advantages, disadvantages, opportunities, and threats of the Langka Sekawan community environmental communication strategy in supporting environmental sustainability, both implemented in Baran, Winong Village, Gempol District, Pasuruan Regency as well as a wider or national scope.

As a result, Langka Sekawan Community can make a difference in society, especially in the culture of the surrounding community which is considered less environmentally friendly. As innovative, creative and independent students as desired positioning, Langka Sekawan 
community tries to implement through work programs. The programs implemented involve the village community. The public is educated to use all environmentally friendly equipment as a substitute for plastic, and after that a screening of the film with the title "Plastic Island" is used as an educational medium.

\section{RESEARCH METHOD}

This research was conducted with a qualitative approach. According to Denzin and Lincoln [6] research with a qualitative approach seeks to describe the natural setting and social phenomena under study. The informants in this research were all members of Langka Sekawan Community, community leaders, and the Baran community. Participant observations and in-depth interviews were conducted in July 2019 to November 2019. Data obtained through participant observation and in-depth interviews will be analyzed using Strengths, Weakness, Oppurtunities, Threaths (SWOT) analysis. This analysis is needed to see the strengths, weaknesses, opportunities, and threats of the communication strategy carried out by the Langka Sekawan community. After a SWOT analysis, the existing data is retested through triangulation of sources and data. All the results of in-depth interviews and observations on the informants were confirmed by sources and interview data on the surrounding community, those who had collaborated with Langka Sekawan and research documentation.

\section{RESULT AND DISCUSSION}

\section{A. Environmental Communication Strategy of Langka Sekawan Community}

Langka Sekawan Community was founded on the basis of concern for all members of the community towards environmental problems that occur around them. So far, Langka Sekawan community is known by the surrounding community as a group of young people who are very active in publishing on social media with creative content pro environmental and natural preservation. The assessment is realized by all members who stated that their activities in social media are one of the leading forms of environmental communication strategy because they are considered the most appropriate way to reach the wider community.

Ideally, the environmental communication strategy consists of 4 major stages, they are: (1) assessment stage, includes situation analysis, problem analysis and the parties involved. (2) planning stage, includes the development of the chosen communication and media strategy. (3) message production stage, which consists of message design and message production. (4) action and reflection stage, includes the distribution of messages through the media, documentation, monitoring and evaluation [7]. From this explanation, it is known that the environmental communication strategy used by Langka Sekawan community are:

\section{1) Assessement Stage}

In this stage, priority problems are found, that is the bad culture of the people who throw trash into the river and the dependence of the community on plastic bags. This situation analysis was carried out in the Baran, Winong Village, Gempol District, Pasuruan Regency. According to Riski (Bara), problems that exist around the community generally also occur in Indonesia with different levels.
The findings above are confirmed by residents of the Baran (Wiwit). According to Wiwit, so far the surrounding community prefers to throw trash into the river because it is considered to be faster and more efficient. This opinion is supported by the statement of Jazuli as the head of the Neighborhood Association (RT) which stated that the accumulation of garbage in the river used to be common before Langka Sekawan community who diligently conducted socialization to the surrounding community.

\section{2) Planning Stage}

Langka Sekawan Community has a work program that is divided into short-term, medium-term and long-term programs. The short-term program of the Langka Sekawan Community are (a) ecobrick training for children, (b) introducing local wisdom, and (c) building environmental literacy. The aim of ecobrick training is to convert plastic waste into commodities that are worth selling. Reintroducing traditional game models to minimize the use of gadgets. The medium-term program of the Langka Sekawan Community is the "Caring for Green Space (MRH)" or reforestation activities carried out on the slopes of the mountains and "Window of the World in a Cup of Coffee, which is interdisciplinary social discussion. The long-term program of the Langka Sekawan Community that wants to be realized in 5 years are Diraloka, Green House, and 3R management (Reduce, Reuse, Recycle). Products from Diraloka include Tshirts with environmental themes, drinking bottles with laser print with environmental themes and selling snacks.

\section{3) Message Production Stage}

The message to be conveyed by Langka Sekawan Community has been contained in the community's jargon, which is "Walk Farther towards the Question Mark". According to the head of Langka Sekawan (Riski), the jargon was inspired by one of the wise words of a figure of Soe Hok Gie. The message is then produced in the short, medium and long term programs above.

\section{4) Action and Reflection Stage}

Langka Sekawan Community divides its environmental communication strategy into two (primary and secondary socialization). In primary socialization, the media used are Instagram, Twitter and YouTube. So far the use of social media is considered the most effective by Langka Sekawan. From the creative content uploaded through the media, LangkaSekawan Community has succeeded in building networks or relationships up to the national level. The primary target of Langka Sekawan Community is the young generation in Indonesia. In secondary socialization, Langka Sekawan Community uses face-to-face communication strategies. With primary socialization through social media, in the end Langka Sekawan Community can join environmental activists called the "Walkers Alliance".

\section{B. SWOT Analysis (Strengths, Weaknesses, Oppurtunities, Threaths)}

\section{1) Strengths}

The strength of Langka Sekawan Community lies in the specialization of each member of the community or Human Resources (HR). For example, the head of Langka Sekawan Community is an individual who has a good leadership and communication network. The community secretary understands the technical community administration and the treasurer has expertise in bookkeeping. Each member has a 
strong will towards self-actualization for the betterment of the community. This is proved by the participation of each member in seminars, workshops and public discussions.

\section{2) Weaknesses}

The weakness of Langka Sekawan Community lies in funding national scale activities. At present Langka Sekawan entrepreneurship division is only able to finance short-term work programs known as daily and weekly programs. Nevertheless, they still try to realize the independence of the community by pioneering Green House and management of waste $3 \mathrm{R}$. In addition, the working hours of each member also becomes a deficiency that must be addressed immediately. Some work programs are hampered because the majority of community members work as students and part-time workers.

\section{3) Oppurtunities}

Until now, Langka Sekawan Community is the only community in Gempol area, Pasuruan that is environmentally oriented. Many local and national NGOs came to Langka Sekawan base camp to review and offer cooperation. However, until now Langka Sekawan does not have a Memorandum of Understanding (MoU) or Memorandum of Agreement (MoA) with NGOs. The head of the community reasoned that he still wanted to study the existing NGOs, because they were afraid of being used and boarded by other interests.

For Langka Sekawan, they already have the heart and energy of the surrounding community when they need help. Besides that, in 2019 they also received support from the Muhammadiyah Sidoarjo University to collaborate in order to realize the Village Variety activities. The hearts and energy of surrounding community are the most important to Langka Sekawan so that they can immediately realize the management of $3 \mathrm{R}$ waste with the community to fund their activities and prosper the poor people in their area.

\section{4) Threaths}

The good cooperation between Langka Sekawan and the surrounding community is not balanced by the collaboration between the stakeholders there. This certainly can be an opportunity that actually threatens the sustainability of Langka Sekawan Community. Determining the meaning of sustainability is a process that involves all types of stakeholders in many contexts, that is people who might disagree with each other [8].

So far, Langka Sekawan has paid less attention to the uncertainty that will arise for community sustainability. Management of the social environment through stakeholders is one of the uncertain factors. Furthermore, other threats actually come from the internal community. Community members totaling 11 people are realized to be one of the threats to the sustainability of their environmental communication strategy. All members are in a dilemma when discussing the number of Langka Sekawan members.

\section{CONCLUSION}

The environmental communication strategy done by Langka Sekawan Community includes: (1) the assessment stage, with the findings of the community's indifference towards environmental sustainability that throw their garbage into the river and people's dependence on plastic. (2) planning stage, Langka Sekawan has a short, medium and long-term program. The segment in the short-term program is the creativity of local children in managing plastic waste, the medium term for all ages on a national scale so that it is wise to use plastic, and the long term for all ages on a national scale to love the environment and local culture more. (3) message production stage, that is constructing social messages through activities in the work program. (4) action and reflection stage. There are two media used, they are social media for primary socialization, and face-to-face media by forming alliances between communities for secondary socialization.

From the identification of the environmental communication strategy above it was found that the strengths of the strategy lie in the specialization and integrity of Langka Sekawan Human Resources, while the most visible weakness is the source of funding for activities and working hours of each member. The opportunity for Langka Sekawan Community to become a pilot community in the surrounding area is wide open because it is the only environment-based community in the area, besides that Langka Sekawan also has relationships with similar communities in Indonesia, and also has community and academic support. The threat posed by Langka Sekawan is the uncertainty of relations with stakeholders and the regeneration of members.

\section{ACKNOWLEDGMENT}

Thanks to the Langka Sekawan Community who have given the opportunity to be the objects and subject of this research and also thanks to the Muhammadiyah Sidoarjo University that has given permission and support this research by providing the research laboratories and research funding.

\section{REFERENCES}

[1] P. Lestari, S. B. Kusumayudha, E. T. Paripurno, and B. Ramadhaniyanto, 'Environmental communication for mount Sinabung eruption mitigation [Komunikasi lingkungan untuk mitigasi bencana erupsi gunung Sinabung]', J. ASPIKOM, vol. 3, no. 1, p. 56, 2016, doi: 10.24329/aspikom.v3i1.98.

[2] U. Wahyudin, 'Environmental communication strategies in building community concern for the environment [Strategi komunikasi lingkungan dalam membangun kepedulian masyarakat terhadap lingkungan]', J. Common, vol. 1, no. 2, pp. 130-134, 2017, doi: 10.34010/common.v1i2.576

[3] D. Wongpaibool, W. Rawang, R. Supapongpichate, and P. Pichayapibool, 'A process of environmental education communication through community cultural activity area', Int. J. Environ. Sci. Educ., vol. 11, no. 12, pp. 5687-5697, 2016.

[4] R. York and P. Mancus, 'Critical human ecology: historical materialism and natural laws*, Sociol. Theory, vol. 27, no. 2, pp. 122149, 2009.

[5] B. Clark and B. J. Foster, 'Florence Kelley and the struggle against the degradation of life: An introduction to a selection from modern industry', Organ. Environ., vol. 19, no. 2, pp. 251-263, 2006, doi: $10.1177 / 1086026606288224$.

[6] K. N. Denzin and Y. S. Lincoln, Handbook of Qualitative Research. Yogyakarta: Pustaka Pelajar, 2009.

[7] R. Cox, Environmental Communication and The Public Sphere, Second. USA: SAGE Publications, 2009.

[8] A. E. J. Wals and L. Schwarzin, 'Fostering organizational sustainability through dialogical interaction', Learn. Organ., vol. 19, no. 1, pp. 1127, 2012, doi: 10.1108/09696471211190338 